\title{
ZnO Nanosheet-Coated TiZrPdSiNb Alloy as a Piezoelectric Hybrid Material for Self-Stimulating Orthopedic Implants
}

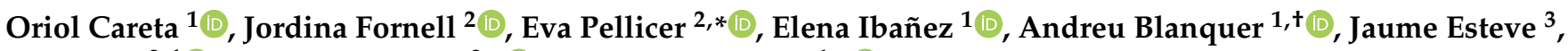

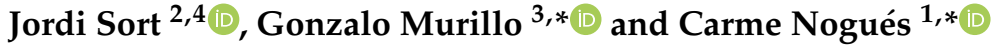 \\ 1 Departament de Biologia Cel-lular, Fisiologia i Immunologia, Universitat Autònoma de Barcelona, \\ E-08193 Bellaterra (Cerdanyola del Vallès), Spain; oriol.careta@uab.cat (O.C.); elena.ibanez@uab.cat (E.I.); \\ andreublanquer@gmail.com (A.B.) \\ 2 Departament de Física, Universitat Autònoma de Barcelona, E-08193 Bellaterra (Cerdanyola del Vallès), Spain; \\ jordina.fornell@uab.cat (J.F.); jordi.sort@uab.cat (J.S.) \\ 3 Instituto de Microelectrónica de Barcelona, IMB-CNM (CSIC), C/del Til-lers, Campus UAB, \\ E-08193 Bellaterra (Cerdanyola del Vallès), Spain; Jaume.Esteve@imb-cnm.csic.es \\ 4 Institució Catalana de Recerca i Estudis Avançats (ICREA), Pg. Lluís Companys 23, E-08180 Barcelona, Spain \\ * Correspondence: eva.pellicer@uab.cat (E.P.); gonzalo.murillo@csic.es (G.M.); carme.nogues@uab.cat (C.N.); \\ Tel.: +34-935812776 (C.N.) \\ + Present Address: Department of Biomaterials and Tissue Engineering, Institute of Physiology of the Czech \\ Academy of Sciences, Videnska 1083, 14220 Prague, Czech Republic.
}

check for

updates

Citation: Careta, O.; Fornell, J.; Pellicer, E.; Ibañez, E.; Blanquer, A.; Esteve, J.; Sort, J.; Murillo, G.; Nogués, C. ZnO Nanosheet-Coated TiZrPdSiNb Alloy as a Piezoelectric Hybrid Material for Self-Stimulating Orthopedic Implants. Biomedicines 2021, 9, 352. https://doi.org/ $10.3390 /$ biomedicines 9040352

Academic Editor: Mike Barbeck

Received: 13 March 2021

Accepted: 27 March 2021

Published: 30 March 2021

Publisher's Note: MDPI stays neutral with regard to jurisdictional claims in published maps and institutional affiliations.

Copyright: (C) 2021 by the authors Licensee MDPI, Basel, Switzerland. This article is an open access article distributed under the terms and conditions of the Creative Commons Attribution (CC BY) license (https:// creativecommons.org/licenses/by/ $4.0 /)$.
Abstract: A Ti-based alloy $\left(\mathrm{Ti}_{45} \mathrm{Zr}_{15} \mathrm{Pd}_{30} \mathrm{Si}_{5} \mathrm{Nb}_{5}\right)$ with already proven excellent mechanical and biocompatibility features has been coated with piezoelectric zinc oxide $(\mathrm{ZnO})$ to induce the electrical self-stimulation of cells. $\mathrm{ZnO}$ was grown onto the pristine alloy in two different morphologies: a flat dense film and an array of nanosheets. The effect of the combined material on osteoblasts (electrically stimulable cells) was analyzed in terms of proliferation, cell adhesion, expression of differentiation markers and induction of calcium transients. Although both $\mathrm{ZnO}$ structures were biocompatible and did not induce inflammatory response, only the array of $\mathrm{ZnO}$ nanosheets was able to induce calcium transients, which improved the proliferation of Saos- 2 cells and enhanced the expression of some early differentiation expression genes. The usual motion of the cells imposes strain to the $\mathrm{ZnO}$ nanosheets, which, in turn, create local electric fields owing to their piezoelectric character. These electric fields cause the opening of calcium voltage gates and boost cell proliferation and early differentiation. Thus, the modification of the $\mathrm{Ti}_{45} \mathrm{Zr}_{15} \mathrm{Pd}_{30} \mathrm{Si}_{5} \mathrm{Nb}_{5}$ surface with an array of $\mathrm{ZnO}$ nanosheets endows the alloy with smart characteristics, making it capable of electric self-stimulation.

Keywords: TiZrPdSiNb alloy; piezoelectric; nanogenerators; self-stimulating; osteoblast; proliferation; differentiation

\section{Introduction}

To be considered as a permanent orthopedic implant, a material must fulfil various criteria. From the mechanical point of view, the material should exhibit high strength, high elastic strain limit and a relatively low Young's modulus to avoid the so-called stressshielding effect and the subsequent implant loosening [1-3]. In turn, the selected material should exhibit good biocompatibility and biostability (i.e., corrosion and hydrolysis resistance), osseointegration, high wear resistance and high bioinertness (i.e., non-toxic, non-allergenic and non-carcinogenic) [3-5]. Among the studied materials, Ti and its alloys $\left(\mathrm{Ti}_{6} \mathrm{Al}_{4} \mathrm{~V}, \mathrm{Ti}_{40} \mathrm{Nb}\right)$ have been established as the most suitable biomaterials for permanent implants in certain applications (i.e., bone and joint replacements) because they exhibit superior mechanical properties, biocompatibility and corrosion resistance [6,7], when compared with other metallic implants, such as stainless steel or Co-Cr alloys $[3,4,8]$.

Nevertheless, these alloys face some problems, such as the presence of non-desirable elements (e.g., $\mathrm{Al}$ and $\mathrm{V}$ in $\mathrm{Ti}_{6} \mathrm{Al}_{4} \mathrm{~V}$ alloys $\left.[9,10]\right)$ or the mismatch between their Young's 
modulus (i.e., $~ 110$ for Ti-6Al-4V [7] and 40-80 for Ti-Nb alloys [11]) and that of the bone (10-30 GPa) [12]. In view of this, ongoing investigations on Ti-based implants are focused on finding new compositions and designs to improve their performance [4,13-15]. One example is our previously designed $\mathrm{Ti}_{45} \mathrm{Zr}_{15} \mathrm{Pd}_{30} \mathrm{Si}_{5} \mathrm{Nb}_{5}$ alloy, with high hardness, a competitive Young's modulus value, and excellent biocompatibility [4].

On the other hand, it is possible to improve the performance and durability of the bioimplants, as well as to modulate the behavior of cells in contact with them, by modifying their surface. Surface modification (i.e., film deposition, laser etching, acid and alkali treatments or anodic oxidation) is an appropriate strategy to modify the surface-dominant properties of the implant without compromising those of the bulk material $[3,15]$. Surface treatments can be employed to improve strength and wear resistance, avoid ion release, or encourage bioactivity between the bone and other tissues $[3,13]$. Coating $\mathrm{Ti}$ and $\mathrm{Ti}$ alloy implants with bioactive ceramic coatings, such as hydroxyapatite $\left(\mathrm{Ca}_{10}\left(\mathrm{PO}_{4}\right)_{6}(\mathrm{OH})_{2}\right)$, which is the principal constituent of hard tissues, is the most explored method to improve bioactivity [13,16-18]. Bioceramic coatings encourage the growth of new bone cells, inhibit the release of metal ions into the surrounding bone tissues, and may promote an earlier osteoid formation. However, the main drawbacks of the hydroxyapatite coatings are the low bond strength and the high residual stress, which may cause its detachment from the implant during long-term service in the human body. Type I collagen coatings have also been considered; some studies have reported their ability to modulate various aspects of cell behavior, such as cell attachment, proliferation, and differentiation on Ti-based implants [12,19-21].

To further increase the performance of bioactive implants, stimulus-responsive biomaterials (i.e., the so-called smart biomaterials) are currently the focus of research because they can also actively participate in the restoration of damaged tissues in response to stimuli (i.e., $\mathrm{pH}$, temperature, electric field, etc.) from their biological environment [3]. To date, most of the reported stimulus-responsive scaffold-based bone implants are made of biodegradable polymers [22-24] and ceramic materials $[25,26]$, but the integration of stimuli-responsive coatings deposited onto metallic scaffolds with excellent mechanical performance remains a challenge.

Within this framework, piezoelectric materials are particularly appealing because they can stimulate electrically excitable cells (e.g., cardiomyocytes, skeletal myotubes, osteoblasts and neural cells) and modulate cell activity as a result of a mechanical stimulus using a non-invasive technique. Due to the piezoelectric effect, these materials can create a charge separation, and a subsequent electric potential, when they are mechanically stressed. To trigger the electrical stimulation, various sources of mechanical actuation, including vibration plates, sounds and ultrasounds, can be employed [27-29]. In fact, piezoelectric nanostructures (i.e., nanoparticles, nanobelts, nanotubes, nanofibers, nanosheets or nanorods) made of boron nitride, barium titanate, $\mathrm{ZnO}$ or polyvinylidene fluoride (PVDF) are attracting strong interest as neural, muscular, or bone cell stimulators [30-37].

In particular, nanostructured $\mathrm{ZnO}$ is widely explored in energy harvesting applications for its ability to generate voltage when mechanically stressed [38], although its use for the electrical stimulation of living cells is much less explored probably because of the contrasting reports about its biosafety [35,39,40]. Nonetheless, Ciofani et al. [35] demonstrated the suitability of $\mathrm{ZnO}$ nanowire arrays in sustaining cellular functions and their potential in applications of tissue engineering and invasive sensing or stimulation. However, no detailed studies to evaluate the effect of stimulation due to the piezoelectric effect have been carried out. In an attempt to elucidate the biocompatibility and the electromechanical $\mathrm{ZnO}$-cell interaction, we previously cultured macrophages and electrically excitable osteoblast-like cells on top of two-dimensional (2D) $\mathrm{ZnO}$ nanosheets grown on an AlN-coated Si substrate [41]. During their growth, the cells induced a local strain to the $\mathrm{ZnO}$ nanosheets, and due to their piezoelectric properties, an electric potential difference was locally generated in the plasma membrane. These $\mathrm{ZnO}-$ cell interactions stimulated the motility of macrophages and triggered the opening of ion channels in the osteoblast-like 
cells, inducing intracellular calcium transients. These results opened the door to promising applications of piezoelectric $\mathrm{ZnO}$ nanosheets in osteogenesis and bone regeneration. However, silicon is not suited for orthopedic applications.

In the present work, a $\mathrm{Ti}_{45} \mathrm{Zr}_{15} \mathrm{Pd}_{30} \mathrm{Si}_{5} \mathrm{Nb}_{5}$ alloy, previously designed by the authors and presenting high hardness, a competitive Young's modulus value, and excellent biocompatibility [4], was coated with $\mathrm{ZnO}$ with the aim of endowing the hybrid material with a new functionality; namely, the capability to stimulate cells without the need to apply an external electric field. Two different $2 \mathrm{D} \mathrm{ZnO}$ structures were tested: a flat dense $\mathrm{ZnO}$-sputtered film, and an array of $\mathrm{ZnO}$ nanosheets. The effect of the combined material on osteoblasts (electrically stimulable cells) was analyzed in terms of proliferation, cell adhesion, expression of differentiation markers and induction of calcium transients.

\section{Materials and Methods}

\subsection{Material Fabrication}

A master alloy with nominal composition $\mathrm{Ti}_{45} \mathrm{Zr}_{15} \mathrm{Pd}_{30} \mathrm{Si}_{5} \mathrm{Nb}_{5}$ (in at.\%) was prepared by arc melting a mixture of the highly pure elements ( $>99.99 \% \mathrm{wt} . \%)$ under a Ti-gettered Ar atmosphere. Rods of $5 \mathrm{~mm}$ in diameter were obtained from the melt by suction casting into a $\mathrm{Cu}$ mold. Further details on sample fabrication and microstructural characterization can be found elsewhere [4]. The as-cast, pristine alloy was cut in disks of about $1 \mathrm{~mm}$ thick and one-side polished with 4000 grid size $\mathrm{SiC}$ paper as a final step for posterior $\mathrm{ZnO}$ deposition. The polished surface of the metallic alloy (referred to as "pristine" alloy) was further modified with $\mathrm{ZnO}$, which was deposited in two different ways: (i) covering the alloy with a thin layer of $\mathrm{ZnO}$ (referred to as " $\mathrm{ZnO}$ thin film"); and (ii) covering the alloy with an array of 2D ZnO nanostructures (referred to as " $\mathrm{ZnO}$ nanosheets") (Figure 1).

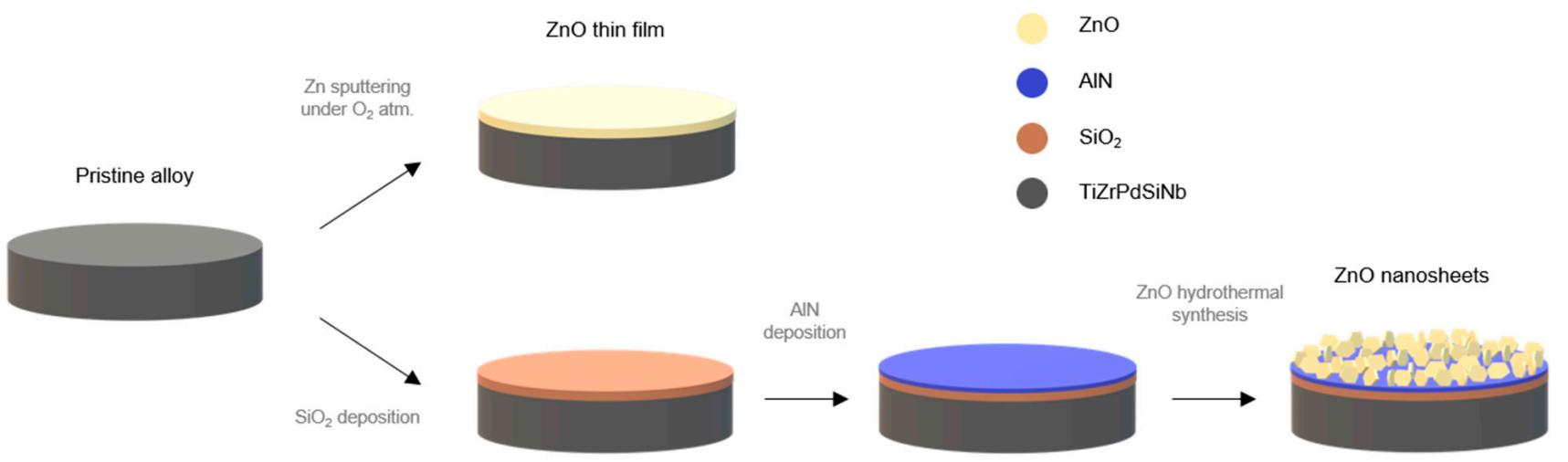

Figure 1. Schematic illustration of the coating process to obtain $\mathrm{ZnO}$ thin films (sputtering) and $\mathrm{ZnO}$ nanosheets (hydrothermal synthesis) on TiZrPdSiNb alloy.

The $\mathrm{ZnO}$ thin film was obtained by sputtering a $\mathrm{Zn}$ target at $100 \mathrm{~W}$ DC for $10 \mathrm{~min}$ under a reactive $\mathrm{O}_{2}$ atmosphere. The $\mathrm{ZnO}$ nanosheets were grown by hydrothermal synthesis. For this, the $\mathrm{Ti}_{45} \mathrm{Zr}_{15} \mathrm{Pd}_{30} \mathrm{Si}_{5} \mathrm{Nb}_{5}$ alloy substrates were placed in a supporting 4-inch silicon wafer to deposit a layer of $1 \mu \mathrm{m}$ of $\mathrm{SiO}_{2}$ by plasma-enhanced chemical vapor deposition as a buffer layer, to avoid the cracking of the posterior layers due to thermal expansion gradients. These processes were performed in a class 100-10,000 cleanroom, with controlled conditions of temperature, pressure, and humidity. Then, a thin-film layer of $100 \mathrm{~nm}$ AlN was deposited by using radio-frequency sputtering on top of the $\mathrm{SiO}_{2}$ layer. An aqueous solution containing hexamethylenetetramine and $\mathrm{Zn}\left(\mathrm{NO}_{3}\right)_{2}$ was poured in a Pyrex container [42,43]. The supporting wafer was placed in the container fixed by four polyether ether ketone screws, with the AlN layer facing down. The container was hermetically closed and introduced in an oven at $80^{\circ} \mathrm{C}$ for $9 \mathrm{~h}$. After the growth was completed, the supported wafer was collected and rinsed in deionized water and ethanol and left to dry at room temperature (RT). Finally, the coated alloy substrates were carefully released from 
the wafer. The growth parameters (i.e., $80{ }^{\circ} \mathrm{C}$ for $9 \mathrm{~h}$ and the aqueous concentration) were optimized in order to improve the activation effect in osteoblast-like cells.

\subsection{Structural Characterization}

The morphology of the pristine alloy, the $\mathrm{ZnO}$ thin film and the $\mathrm{ZnO}$ nanosheets deposited on top was studied by scanning electron microscopy (SEM) on Zeiss Auriga and Merlin microscopes.

The composition of the samples was determined by energy-dispersive $\mathrm{X}$-ray spectroscopy (EDS/EDX). EDX measurements of the base alloy were carried out at $15 \mathrm{kV}$, whereas those on the $\mathrm{ZnO}$ structures were obtained at lower voltages $(2-5 \mathrm{kV})$ in order to restrict the penetration of the $\mathrm{X}$-rays to the utmost $\mathrm{ZnO}$. Grazing incidence $\mathrm{X}$-ray diffraction (GIXRD) analyses were conducted on a Malvern-PANalytical X'Pert Pro MRD diffractometer using $\mathrm{CuK} \alpha$ radiation for phase analysis of the samples in a $2 \theta$ range from $30^{\circ}$ to $80^{\circ}$.

\subsection{Cell Culture}

Human osteosarcoma Saos-2 cells (ATCC HTB-85) were cultured in Dulbecco's modified Eagle's medium (DMEM) (Gibco, ThermoFisher Scientific, Waltham, MA, USA) supplemented with $10 \%$ fetal bovine serum (FBS; Gibco), under standard conditions $\left(37^{\circ} \mathrm{C}\right.$, $5 \% \mathrm{CO}_{2}$ ). Saos-2 cell line derives from osteosarcoma, and even though it could show some minor disparities in terms of cellular behavior when compared with primary human osteoblasts, Saos- 2 cells have been widely used to test the biocompatibility of newly developed materials for a wide range of biomedical applications, being considered as a representative model of multiple osteoblast responses [44]. The samples (pristine alloy, used as controls in all experiments, $\mathrm{ZnO}$ thin film, and $\mathrm{ZnO}$ nanosheets) were sterilized with absolute ethanol for $30 \mathrm{~min}$ and individually introduced into a 4- or a 24-well plate. Then, different numbers of cells, depending on the experiment, were seeded into each well.

THP-1 monocyte cells were used to analyze the immunological response to alloy samples. Monocytes were grown in RPMI 1640 medium (Gibco) supplemented with 25\% FBS under standard conditions. To differentiate monocytes into macrophages, 400,000 THP-1 cells were seeded into 24-well plates and treated with $0.16 \mu \mathrm{M}$ phorbol-12-myristate13-acetate (Sigma-Aldrich, Saint Louis, MO, USA) for $72 \mathrm{~h}$. Then, cells were washed and incubated in fresh medium for $24 \mathrm{~h}$ before carrying out the experiments.

\subsection{Quantification of Cell Proliferation}

Osteoblast proliferation was determined using Alamar Blue cell viability reagent (Thermo Fisher Scientific) at days 1,3 and 7. Briefly, 250,000 cells were seeded into each well of a 24-well plate containing each sample (pristine alloy, $\mathrm{ZnO}$ thin film and $\mathrm{ZnO}$ nanosheets). After $24 \mathrm{~h}$, samples with adhered cells were moved to a new well to discard cells growing outside the surface of the alloys. Fresh medium with $10 \%$ Alamar Blue was added, and cells were incubated for $4 \mathrm{~h}$ in the dark and standard conditions. Then, the supernatant was collected, and its fluorescence was measured at $585 \mathrm{~nm}$ wavelength after excitation at $560 \mathrm{~nm}$ on a Varian Cary Eclipse Fluorimeter (Agilent Technologies, Santa Clara, CA, USA). Fresh medium was added to the cultures and the assay was repeated after 3 and 7 days. Experiments were performed in triplicate.

\subsection{Quantification of Inflammatory Cytokines Secretion}

To conduct these experiments, THP-1 cells differentiated into macrophages were used. A previously sterilized alloy sample was placed on a $6.5 \mathrm{~mm}$ Transwell ${ }^{\circledR}$ with a $0.4 \mu \mathrm{m}$ Pore Polyester Membrane Insert (Corning, Corning, NY, USA) placed over the macrophage cultures (cell culture insert system) and maintained in close contact with the cells for $24 \mathrm{~h}$ to analyze the secretion of inflammatory cytokines. As a positive control, $1 \mu \mathrm{g} / \mathrm{mL}$ of lipopolysaccharide (LPS) (Sigma-Aldrich) was added to the macrophages culture. As a negative control, macrophages were cultured in the absence of the alloys or LPS. After 
$24 \mathrm{~h}$, supernatants were collected and used to quantify cytokine secretion. Inflammatory cytokines TNF- $\alpha$, IL-1 $\beta$ and IL- 6 were evaluated by flow cytometry using cytometric bead array (CBA) (Becton-Dickinson, East Rutherford, NJ, USA). Cytokine concentrations in the supernatant were analyzed according to the manufacturer's protocol. Negative control was considered as basal secretion level with a 0 value. Experiments were performed in triplicate.

\subsection{Cell Adhesion Analysis}

Cell adhesion was determined through the analysis of focal contacts by actin filaments and vinculin detection. In these studies, 100,000 cells were seeded onto the different samples and, after $72 \mathrm{~h}$, alloys were washed twice in PBS and cells fixed in $4 \%$ paraformaldehyde in PBS for 15 min at RT. After washing twice in PBS, cells were permeabilized with $0.1 \%$ Triton X-100 (Sigma-Aldrich) in PBS for $15 \mathrm{~min}$ and blocked for $25 \mathrm{~min}$ with 1\% bovine serum albumin (BSA) (Sigma-Aldrich), 0.5\% Tween 20 (Sigma-Aldrich) in PBS at RT. Samples were then incubated with a mouse anti-vinculin primary antibody (Millipore, MAB3574) at $2 \mu \mathrm{g} / \mathrm{mL}$ overnight at $4{ }^{\circ} \mathrm{C}$ and washed with $1 \%$ BSA- $0.5 \%$ Tween 20 in PBS. Then, samples were incubated with a mixture of Alexa fluor 594-conjugated phalloidin (Invitrogen, ThermoFisher Scientific, Waltham, MA, USA), Alexa fluor 488 chicken antimouse IgG (Invitrogen), and Hoechst 33,258 (Sigma-Aldrich) for 60 min in the dark at RT. Finally, cells were washed in PBS, air-dried, and mounted on specific bottom glass dishes (MatTek, Ashland, MA, USA) using ProLong Antifade mounting solution (Life Technologies, Carlsbad, CA, USA). Immunofluorescence evaluation was performed in a confocal laser scanning microscope (CLSM) (Olympus, Shinjuku, Tokyo, Japan).

\subsection{Cell Morphology Analysis}

A total of 250,000 cells were seeded into each well of a 24-well plate containing each type of sample and cultured for 7 days. Then, cells were processed to be analyzed by SEM. Briefly, cells were washed in cold phosphate buffered saline (PBS), fixed in $4 \%$ paraformaldehyde in PBS for $15 \mathrm{~min}$ at RT, and washed again in PBS. Cell dehydration was performed in a series of increasing ethanol concentrations (50, 70, 90 and twice 100\%) for $8 \mathrm{~min}$ each. Finally, samples were dried using hexamethyldisilazane (Electron Microscopy Sciences, Hatfield, PA, USA) for $15 \mathrm{~min}$. Samples were mounted on special stubs and analyzed using an SEM Merlin (Zeiss, Oberkochen, Germany) in order to observe cell morphology.

\subsection{Intracellular Calcium Measurement}

Time-lapse CLSM (Leica SP5) (Leica, Wetzlar, Germany) was used to measure the intracellular calcium dynamics over time. Briefly, 100,000 Saos-2 cells were seeded on a 4-well plate containing an alloy sample. Cells were incubated for $24 \mathrm{~h}$ in standard conditions, and then were loaded with $2 \mu \mathrm{M}$ Fluo- 4 AM (Life Technologies) in serum-free DMEM for $30 \mathrm{~min}$ in the dark at RT. Samples were washed with serum-free DMEM and then placed upside-down into MatTek dishes with fresh medium without phenol red. Images of osteoblasts were captured in time-lapse CLSM every $1 \mathrm{~s}$ for $30 \mathrm{~min}$. Changes in fluorescence intensity during the time of monitoring were processed using Image J software.

A MATLAB code was developed to automatically detect $\beta \beta^{+}$influx in cells, using the time-lapse videos recorded in the CLSM as the data source. This code uses several image enhancement routines and perimeter detection algorithms to identify all the cultured cells. The centroid, pixel coordinates, and the area of each cell larger than 30 pixels are stored in a data structure to be processed. Then, for each particular cell, the mean relative intensity over time was calculated and used as the input of an ad hoc peak detector to evaluate whether the cell was electrically activated by the associated $\mathrm{ZnO}$ piezoelectric effect or not. 


\subsection{Quantitative Real-Time PCR}

The expression of osteogenic marker genes encoding alkaline phosphatase (ALPL), osteocalcin (BGLAP), type I collagen (COL1), bone sialoprotein (IBSP), osteonectin (SPARC) and osteopontin (SPP1) was analyzed by real-time quantitative polymerase chain reaction (qPCR). For gene expression analysis, 100,000 cells were seeded onto samples and, at 7, 14 and 21 days, total RNA was extracted from the cell cultures using the Maxwell RSC simplyRNA tissue kit (Promega, Madison, WI, USA) according to the manufacturer's protocol. RNA concentration and purity were determined using a Nanodrop spectrophotometer (Nanodrop 1000, Thermo Scientific, ThermoFisher Scientific). Reverse transcription was performed with $500 \mathrm{ng}$ total RNA using the iScript cDNA synthesis kit (BioRad, Hercules, CA, USA), according to the manufacturer's instructions. The mRNA levels were assayed in triplicate in CFX384 arrays (BioRad) using $5 \mu \mathrm{L}$ of iTaq Universal SYBR Green Supermix (BioRad), $0.5 \mu \mathrm{L}$ of PrimePCR Assays (BioRad) and $20 \mathrm{ng}$ cDNA in a total volume of $10 \mu \mathrm{L}$. The PCR amplification was performed as follows: initial heating at $95{ }^{\circ} \mathrm{C}$ for $3 \mathrm{~min}$, followed by 40 cycles at $95^{\circ} \mathrm{C}$ for $10 \mathrm{~s}, 60^{\circ} \mathrm{C}$ for $30 \mathrm{~s}$, and a final melt curve from $65^{\circ} \mathrm{C}$ to $95^{\circ} \mathrm{C}$, in $0.5^{\circ} \mathrm{C}$ increment each $5 \mathrm{~s}$ in a C1000 Touch Thermal Cycler (BioRad). Expression values were obtained from cycle quantification $(\mathrm{Cq})$ values determined with the BioRad CFX Maestro ${ }^{\mathrm{TM}}$ Software. The target gene levels are expressed as a relative value: the ratio of the target gene expression to that of the reference TATA-box binding protein (TBP) and hypoxantine phosphoribosyltranferase (HPRT1) genes. The relative gene expression was calculated as $2-\Delta \mathrm{Cq}$. Validated PrimePCR SYBR Green Assays (BioRad) for ALPL (qHsaCID0010031), BGLAP (qHsaCED0038437), COL1 (qHsaCED0043248), IBSP (qHsaCED0002933), SPARC (qHsaCID0010332), SPP1 (qHsaCID0012060), TBP (qHsaCID0007122) and HPRT1 (qHsaCID0016375) were used.

\subsection{Statistical Analysis}

All quantitative data were analyzed with GraphPad Prism 6 (GraphPad Software Inc., San Diego, CA, USA) and presented as the mean \pm standard deviation. Statistical comparisons were performed using one-way analysis of variance (ANOVA) with the Tukey-Kramer multiple comparison test for cell proliferation assays. Multiple comparison procedures were performed with ANOVA using the Student-Newman-Keuls method for gene expression values. A value of $p<0.05$ was considered to be significant. Significance is represented in the figures using an alphabetical superscript system on top of the columns. Values with different alphabetical superscripts are significantly different, whereas values with the same alphabetical superscripts do not significantly differ.

\section{Results}

\subsection{Morphology, Composition and Structure of the Samples}

The morphology of the pristine $\mathrm{Ti}_{45} \mathrm{Zr}_{15} \mathrm{Pd}_{30} \mathrm{Si}_{5} \mathrm{Nb}_{5}$ base alloy and the $\mathrm{ZnO}$ materials deposited on top (Figure 1), i.e., the sputtered thin film and the hydrothermally synthesized nanosheets, can be seen in the SEM images of Figure 2a-c. The composite-like microstructure of the base alloy (the eutectic lamellae in particular) is visible in Figure 2a. The sputtered $\mathrm{ZnO}$ thin film was featureless, likely due to is reduced thickness (around $30 \mathrm{~nm}$ ) and very low surface roughness (Figure $2 \mathrm{~b}$ ). Meanwhile, the surface of the alloy covered by $\mathrm{ZnO}$ nanosheets was much rougher, due to the lamellar structure produced by the high aspect ratio and smooth $\mathrm{ZnO}$ crystalline array showing a hexagonal sheet morphology, with an average thickness of $25 \pm 8 \mathrm{~nm}$ (Figure 2c). The constituting elements of the pristine alloy are all present in its corresponding EDX pattern (Figure 2d), with an atomic ratio close to the nominal one (i.e., $\mathrm{Ti}_{42} \mathrm{Zr}_{17} \mathrm{Pd}_{31} \mathrm{Si}_{6} \mathrm{Nb}_{4}$ ). The EDX pattern of the $\mathrm{ZnO}$ thin film (which was acquired at a low voltage to maximize the response from the $\mathrm{ZnO}$ layer) shows the signals of $\mathrm{Zn}$ and $\mathrm{O}$ (Figure 2e). Figure $2 \mathrm{f}$ depicts the GIXRD patterns of the pristine alloy and the $\mathrm{ZnO}$ nanosheets. The most intense peaks for the base alloy belong to the cubic $\beta$-Ti phase $(\operatorname{Im} 3 \mathrm{~m})$, although $\beta$-Ti reflections partially overlap with $\alpha-\mathrm{Ti}$, as previously demonstrated [4]. On the other hand, the GIXRD pattern of the $\mathrm{ZnO}$ 
nanosheets grown onto $\mathrm{Ti}_{45} \mathrm{Zr}_{15} \mathrm{Pd}_{30} \mathrm{Si}_{5} \mathrm{Nb}_{5}$ shows reflections corresponding to the metallic alloy beneath and new reflections matching the hexagonal phase of $\mathrm{ZnO}$ (wurtzite). Note that the $\mathrm{ZnO}$-sputtered thin film did not diffract, probably because of its small thickness.
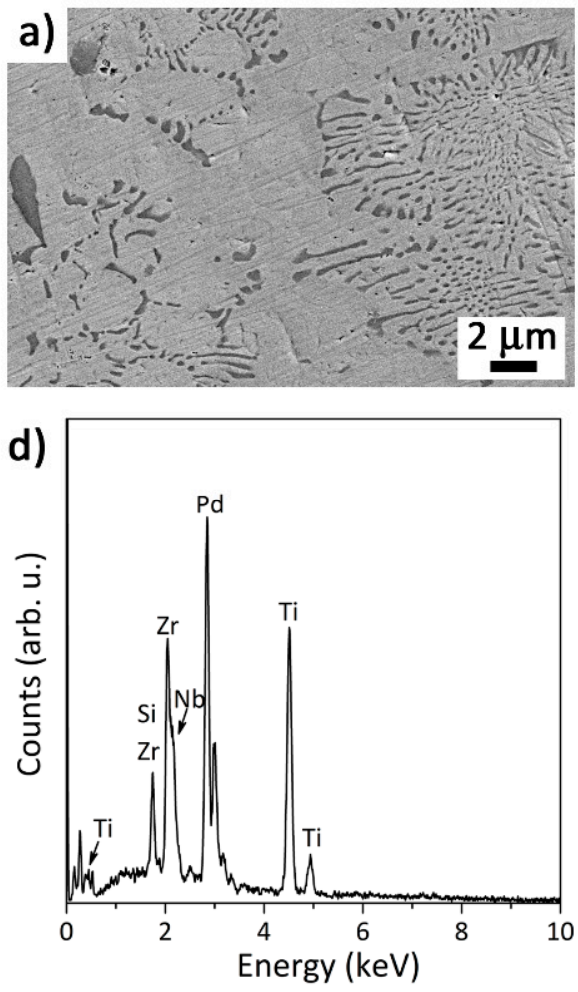
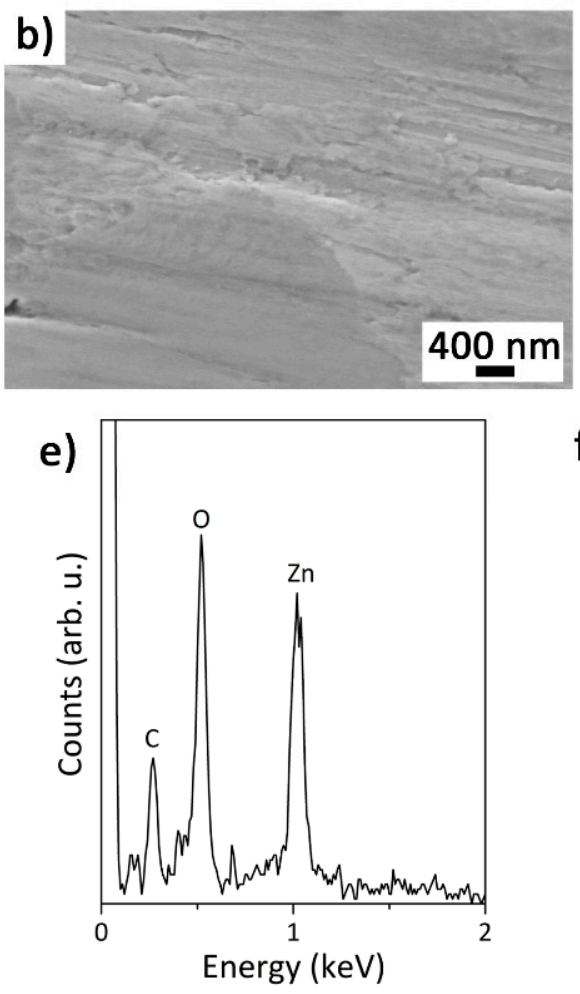
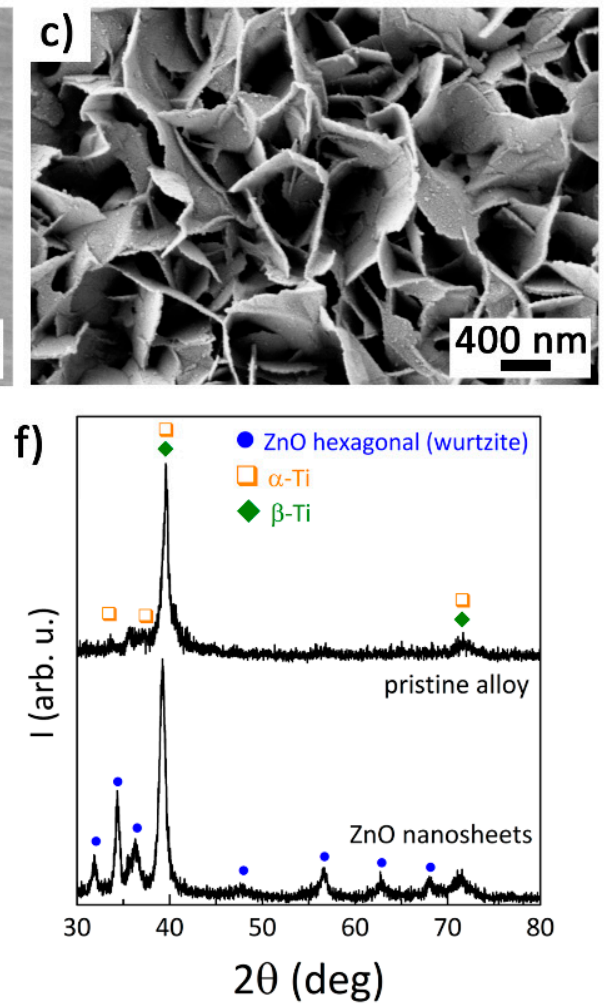

Figure 2. SEM images of (a) pristine alloy, (b) $\mathrm{ZnO}$ thin film, and (c) $\mathrm{ZnO}$ nanosheets deposited on top. EDX patterns of (d) pristine alloy and (e) ZnO thin film samples. (f) Grazing incidence X-ray diffraction (GIXRD) patterns of pristine alloy and $\mathrm{ZnO}$ nanosheets.

\subsection{Cell Proliferation}

The proliferation of Saos-2 cells grown on the different samples (pristine, $\mathrm{ZnO}$ thin film and $\mathrm{ZnO}$ nanosheets) was quantified after one, three and seven days of seeding. Results were normalized with respect to the viability at day 1 and compared among materials at each time-point. As shown in Figure 3, the number of cells growing on the pristine alloy and on the $\mathrm{ZnO}$ thin film were similar at all time-points. By contrast, the number of cells growing on $\mathrm{ZnO}$ nanosheets at day 7 was significantly higher than on the other two surfaces.

\subsection{Induction of Inflammatory Cytokine Secretion}

To find out whether the elements present in the metallic alloy or the different $\mathrm{ZnO}$ coatings activated the secretion of inflammatory cytokines, macrophages were cultured in the presence of the three samples using a cell culture insert system. CBA results showed that the presence of any of the three materials did not activate the secretion of TNF- $\alpha$, IL- 6 , or IL-1 $\beta$ in macrophages (Figure 4). However, when macrophages were exposed to LPS (positive control), a significant increase in the concentration of the three cytokines was detected in the culture medium. 


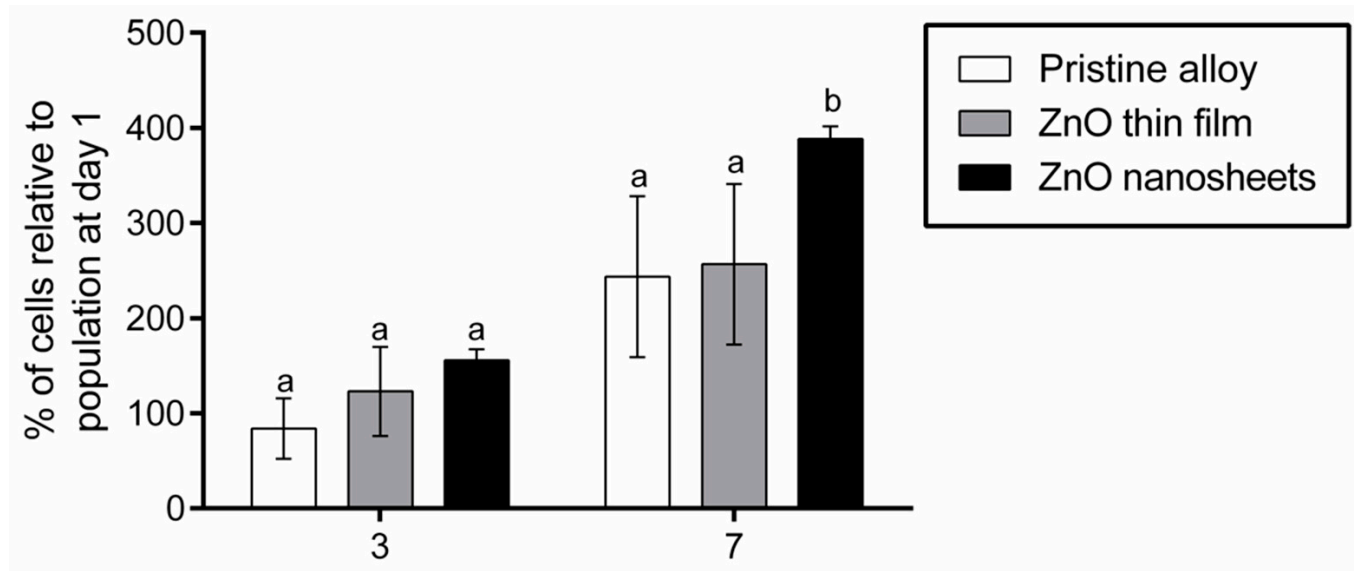

Time (days)

Figure 3. Proliferation of Saos-2 cells grown on pristine alloy, $\mathrm{ZnO}$ thin film, and $\mathrm{ZnO}$ nanosheets at 3 and 7 days in culture. Results were normalized by day 1. Different superscripts on top of the columns denote significant differences $(p<0.05)$ among the materials at the same time-point.

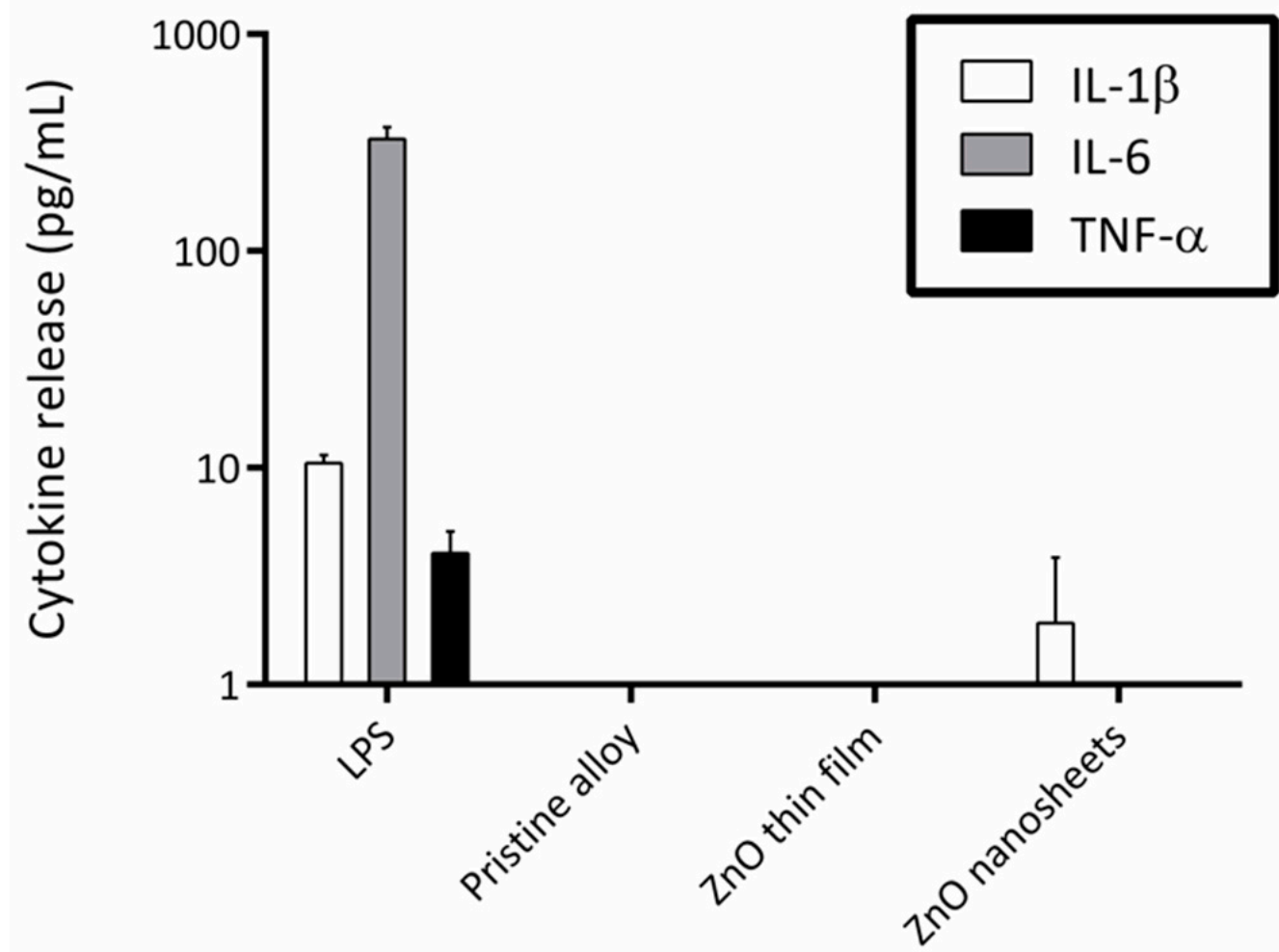

Figure 4. Logarithmic representation of cytokine release by macrophages cultured in the presence of lipopolysaccharide (LPS) (positive control) and the three different samples. Secretion was analyzed by the cytometric bead array (CBA) test at $24 \mathrm{~h}$ of culture. Error bars indicate the standard error of the mean of three replicas.

\subsection{Cell Morphology and Adhesion Analysis}

Immunofluorescence analysis of vinculin and stress fibers (actin) showed that osteoblasts were completely adhered to the sample surface after three days of culture (Figure 5) and were able to establish focal contacts with all surfaces. Stress fibers were well defined, some of them crossing the totality of the cell and some of them ending 
in a focal contact. Stress fibers were found either in a parallel orientation or without a defined orientation.

SEM analysis of osteoblasts grown on the different samples showed that cells were randomly distributed on their surfaces after seven days of culture (Figure 6). In all cases, cells presented a flattened polygonal morphology with cytoplasmic extensions in different directions. Moreover, cells established contacts with nearby cells through thin plasma membrane projections, and most of the cells presented several nucleoli in their nucleus. Cells growing on $\mathrm{ZnO}$ nanosheets emitted long membrane projections that anchored directly on the nanosheets (Figure 6f).
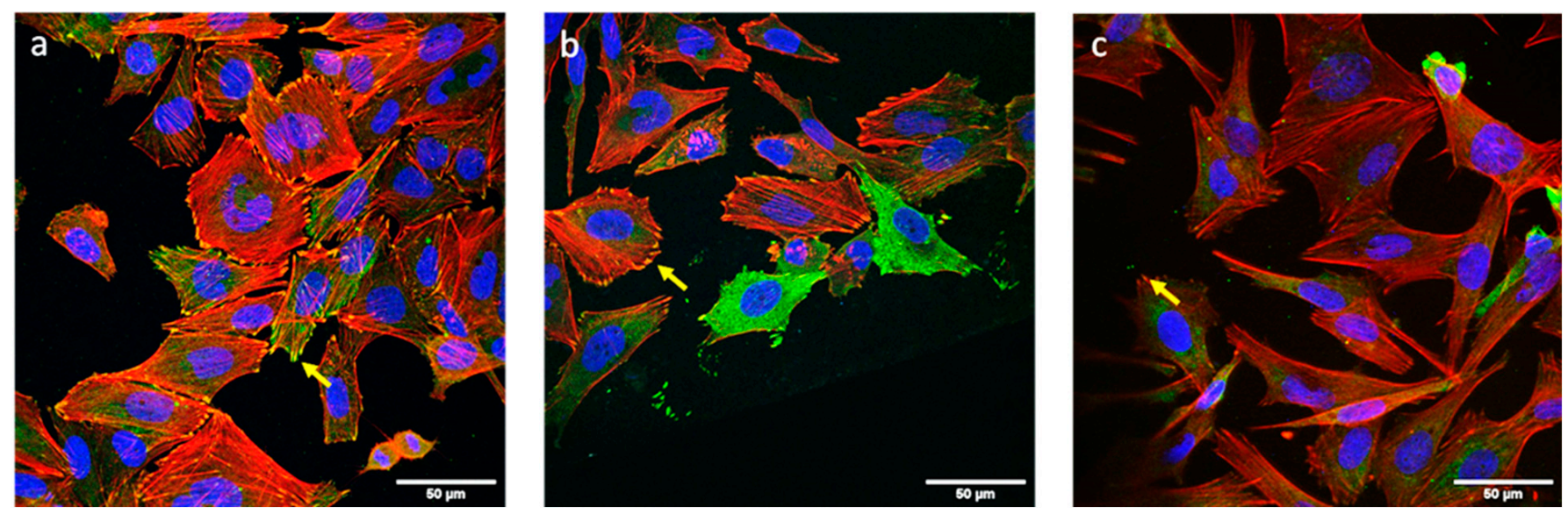

Figure 5. Saos-2 cells adhered to the surface of the pristine alloy (a), ZnO thin film (b), and ZnO nanosheets (c) after 3 days in culture. Stress fibers (actin; red), vinculin (green) and nuclei (DNA; blue) can be observed. Focal contacts (yellow arrows) appear as yellow spots due to the overlay of actin and vinculin signals.

\subsection{Induction of Intracellular Calcium Transients}

The analysis of intracellular calcium transients induced by the three types of samples can be seen in Figure 7. A low percentage of Saos-2 cells grown on the pristine alloy $(8.00 \% \pm 4.58 \%)$ and the $\mathrm{ZnO}$ thin film $(5.33 \% \pm 3.05 \%)$ experienced transient increases in $\mathrm{Ca}^{2+}$ concentration. By contrast, $46.50 \% \pm 4.95 \%$ of Saos- 2 cells grown on the $\mathrm{ZnO}$ nanosheets were activated, presenting intracellular calcium transients.

\subsection{Expression of Osteogenic Markers}

Finally, we analyzed the expression of six specific osteogenic marker genes encoding alkaline phosphatase (ALPL), osteocalcin (BGLAP), type I collagen (COL1), bone sialoprotein (IBSP), osteonectin (SPARC), and osteopontin (SPP1) after 7, 14 and 21 days in culture on the three samples in standard conditions (Figure 8). In general, marker gene expression was similar or significantly higher on cells grown on $\mathrm{ZnO}$ nanosheets when comparing all three materials at 7, 14 or 21 days of culture. The only exceptions were IBSP at day 7, of which the expression was significantly lower on $\mathrm{ZnO}$ thin film; COL1 and IBSP at 14 days, of which the expression was significantly lower in cells grown on $\mathrm{ZnO}$ nanosheets; and SPARC at day 21, of which the expression was significantly higher in cells grown on $\mathrm{ZnO}$ thin film, even though expression in cells grown on $\mathrm{ZnO}$ nanosheets was also higher than in cells grown on pristine alloys. 

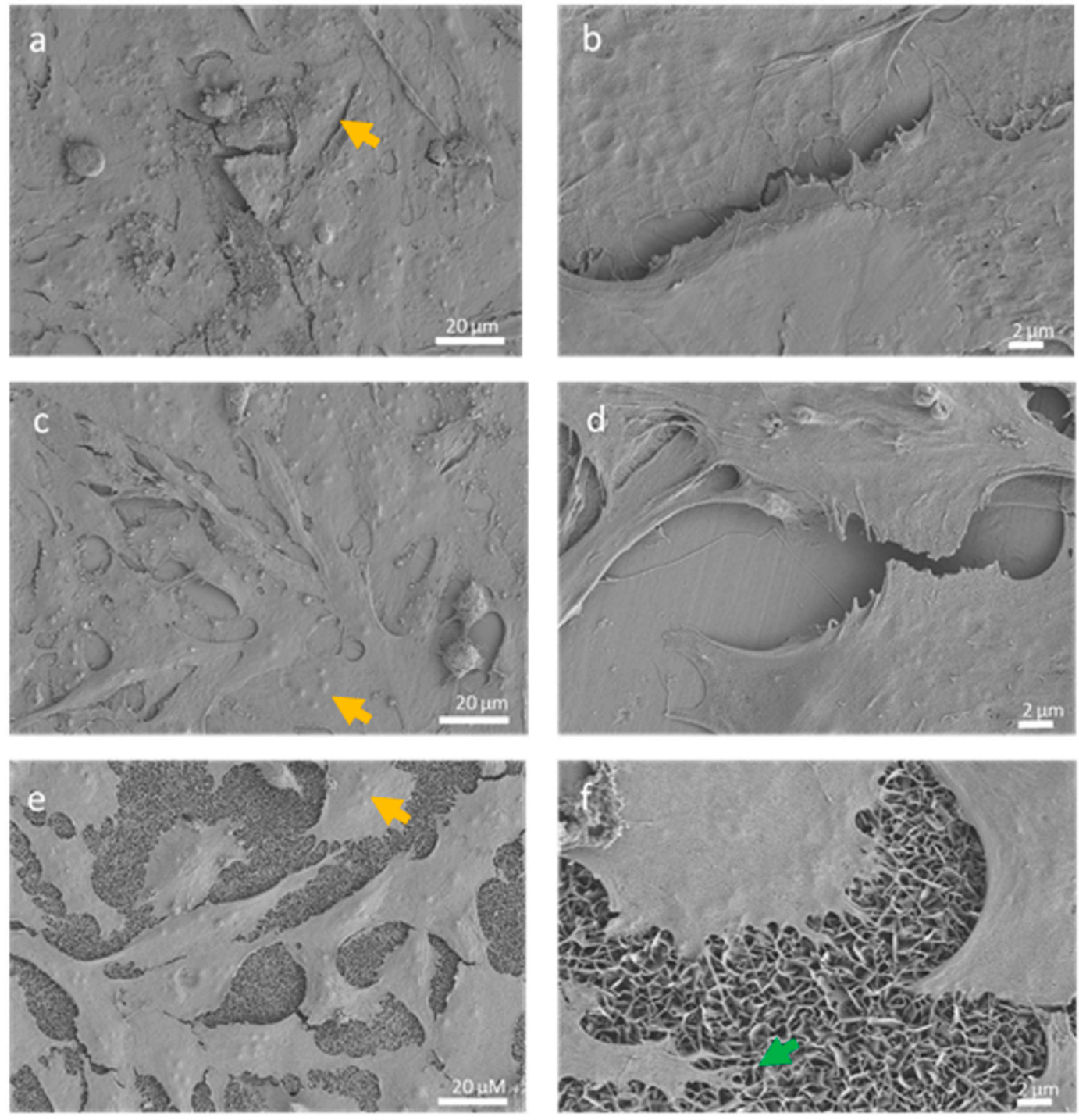

Figure 6. SEM images of Saos-2 cells cultured for 7 days on pristine alloy (a,b), ZnO thin film (c,d), or ZnO nanosheets (e,f). Several nucleoli can be seen inside nuclei (yellow arrows). Long projections are anchored directly on the nanosheets (green arrow).

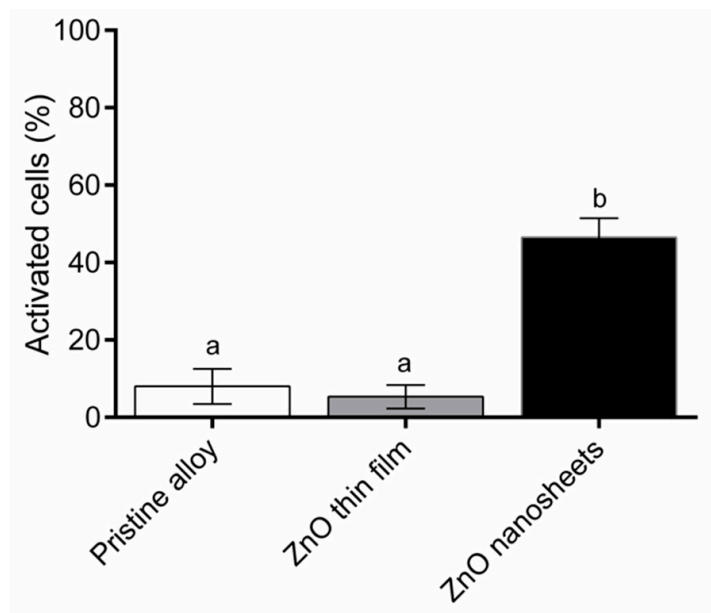

Figure 7. Percentage of activated osteoblastic (Saos-2) cells which underwent transient changes in intracellular calcium concentration when grown on top of the different samples. Different superscripts on top of the columns denote significant differences $(p<0.05)$ among the materials. 

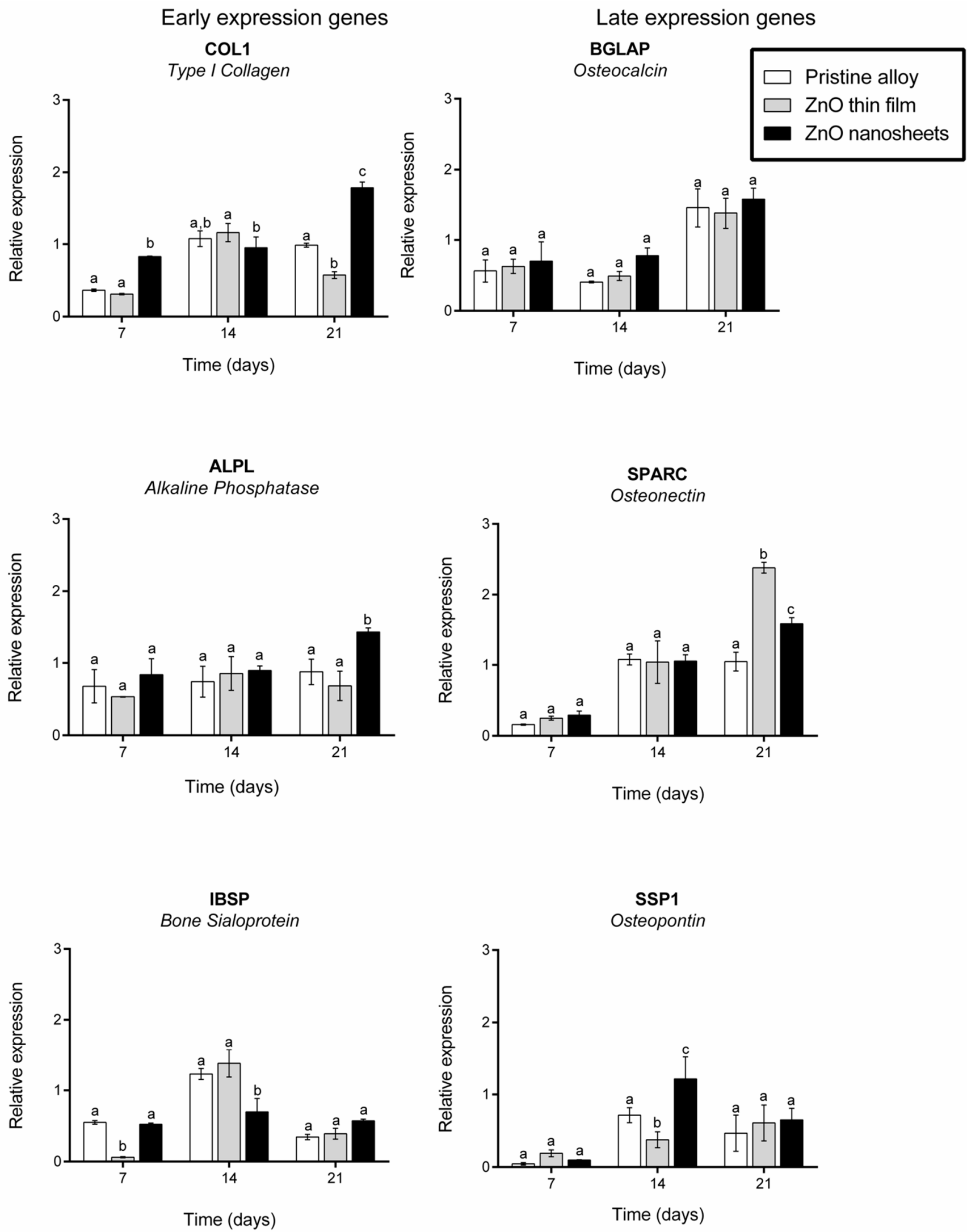

Figure 8. Quantification of mRNA levels. Relative expression of osteoblast differentiation markers COL1, ALP, BGLAP, IBSP, SPARC and SPP1 (under the protein encoded) in Saos-2 cells on day 7, 14 and 21 after seeding on the three samples. The target gene levels are expressed as a relative value. Different superscripts on top of the columns denote significant differences $(p<0.05)$ among the materials at the same time-point. 


\section{Discussion}

Nanostructured $\mathrm{Ti}_{45} \mathrm{Zr}_{15} \mathrm{Pd}_{30} \mathrm{Si}_{5} \mathrm{Nb}_{5}$ alloy with predominant $\beta$-type phase was previously synthesized and characterized by our group [4]. It showed a good combination of mechanical properties, with reduced Young's modulus around $85 \mathrm{GPa}$ and hardness around $10.4 \mathrm{GPa}$. Indeed, the addition of 5 at. $\% \mathrm{Nb}$ to the TiZrPdSi alloy was proven to decrease the Young's modulus from $117 \mathrm{GPa}$ to $85 \mathrm{GPa}$, thus making it closer to that of the bone. Importantly, we also demonstrated that the addition of $\mathrm{Nb}$ to the alloy enhanced osteoblast-like cell (Saos-2) adhesion and proliferation, and that cells grown onto the TiZr$\mathrm{PdSiNb}$ alloy presented higher levels of some late osteogenic markers during the first week in culture [45]. On the other hand, in a separate work, we showed that the interaction of living cells with piezoelectric $\mathrm{ZnO}$ nanogenerators induces a local electric field that self-stimulates and modulates cell activity, without the need of an additional chemical or physical external stimulation [41].

In the present study, we combined the characteristics of both materials to obtain a hybrid $\mathrm{Ti}_{42} \mathrm{Zr}_{17} \mathrm{Pd}_{31} \mathrm{Si}_{6} \mathrm{Nb}_{4}$ alloy covered with $\mathrm{ZnO}$ nanosheets, capable of acting as an implantable orthopedic material with cell self-stimulation characteristics while, in turn, improving cell proliferation and differentiation. To analyze the effect on cell behavior of the $\mathrm{ZnO}$ counterpart as a piezoelectric material, we coated some samples of pristine alloy with a flat, thin, $\mathrm{ZnO}$ layer and, separately, others with an array of $\mathrm{ZnO}$ nanosheets. We evaluated the self-stimulation activity of cells grown on the hybrid material using Saos-2, because they present voltage-gated calcium channels and stretch-activated cation channels in their membranes [46], and the opening of these channels can be triggered by electric fields. It is known that the external electrical stimulation of osteoblasts increases their proliferation and differentiation [47].

First, biocompatibility was analyzed in terms of cell proliferation on days 3 and 7 . None of the $\mathrm{ZnO}$ coatings caused a decrease in Saos-2 viability, confirming that $\mathrm{ZnO}$ is not cytotoxic. The techniques used to coat the alloy (sputtering and hydrothermal growth) had no negative effect on cell viability (e.g., they did not leave remains of toxic solvents) and the layers remained attached to the alloy during the entire duration of the experiments. Cell proliferation was similar between $\mathrm{ZnO}$ thin film and pristine alloy samples at all time points analyzed but, interestingly, $\mathrm{ZnO}$ nanosheets increased Saos-2 proliferation on day 7 compared with the other two types of samples. The biocompatibility of the pristine alloy and the $\mathrm{ZnO}$ nanosheets had already been determined in previous studies by our group [41,45], but the effect of the flat $\mathrm{ZnO}$ layer and the procedures used to attach the $\mathrm{ZnO}$ materials to the pristine alloy on cell proliferation had not been investigated. Although $\mathrm{ZnO}$ is generally recognized as a safe material by the Food and Drug Administration (FDA) of the United States, controversial results have been reported on its cytotoxicity. It has been described that $\mathrm{ZnO}$ nanorods inhibit cell adhesion [48], although $\mathrm{ZnO}$ nanoflowers improved cell proliferation when compared with $\mathrm{ZnO}$ films [49]. All these results suggest that cytotoxicity depends on the specific shape of $\mathrm{ZnO}$. According to our results, both the $\mathrm{ZnO}$ thin film and the nanosheets array are not cytotoxic, and the latter also enhances osteoblast proliferation.

Secondly, and related to biocompatibility, the possibility that these materials could trigger an inflammatory response was analyzed by quantifying the secretion of three cytokines involved in inflammation. None of the materials tested increased the release of inflammatory cytokines under study compared with the pristine alloy. Even though biomaterials are generally non-toxic, they can mediate adverse reactions such as inflammation, and it is important to discard this problem because inflammation may end in implant failure [50,51].

Once the safeness of the hybrid materials was demonstrated, we analyzed the adhesion and morphology of osteoblasts grown on them. It is well known that surface topography can modulate cell adhesion, morphology and cell-material interactions $[52,53]$. Cell adhesion and spreading are important to prevent aseptic loosening of the implants caused by fibroblast layer attachment [50]. No differences in adhesion or morphology 
were found among the three samples, even though the topography of the $\mathrm{ZnO}$ nanosheets and $\mathrm{ZnO}$ thin film or pristine alloy was different. Actin stress fiber distribution and focal contacts were also similar among cells grown on the three materials. It has been described that small differences in the order of nanometers could improve cell attachment and, in turn, proliferation, because osteoblasts need to adhere to proliferate and differentiate $[52,53]$. As mentioned before, the $\mathrm{ZnO}$ nanosheets enhance osteoblast proliferation although, apparently, no differences in adhesion were observed.

The next step was to test whether the samples with the $\mathrm{ZnO}$ layer presented piezoelectric properties. A piezoelectric material is a material that generates an electric field when mechanically deformed and vice versa, i.e., it deforms when an electric field is applied. In a previous study [41], we had shown that the typical movements of cells in culture are sufficient to cause small deformations (strain) to the partially clamped $\mathrm{ZnO}$ nanostructures, thereby inducing small local electric fields. It is also known that osteoblasts exposed to an electrical field can exhibit changes in their cytosolic calcium concentration [46,54] and, because $\mathrm{Ca}^{2+}$ is a secondary messenger involved in numerous transduction pathways [47], these $\mathrm{Ca}^{2+}$ transients can enhance proliferation and/or differentiation. Cell adhesion was excellent on all three materials; therefore, one possible explanation for the higher cell proliferation on the $\mathrm{ZnO}$ nanosheets compared to the $\mathrm{ZnO}$ thin film and pristine alloy could be the existence of an electrical stimulation due to the piezoelectric effect present in the $\mathrm{ZnO}$ nanosheets, arising from cell-induced strains. Note that such strains cannot develop in the sputtered $\mathrm{ZnO}$ thin film because of the full mechanical clamping with the metallic $\mathrm{Ti}_{45} \mathrm{Zr}_{15} \mathrm{Pd}_{30} \mathrm{Si}_{5} \mathrm{Nb}_{5}$ base alloy, which is rigid. Such clamping is much more limited in the case of $\mathrm{ZnO}$ nanosheets due to the reduced interface contact area between the sheets and the base alloy, obtaining nanostructures capable of bending. Hence, our results suggest that only metallic alloys whose surface is covered with $2 \mathrm{D}$ nanostructured $\mathrm{ZnO}$ (i.e., $\mathrm{ZnO}$ nanosheets), as shown here, are able to induce a local electric field large enough to stimulate the cells and alter their activity, allowing the opening of the calcium channels and the influx of calcium from the external medium.

Finally, to study the effect of all materials in osteoblast differentiation, the expression of genes related to osteoblast differentiation were analyzed. The differentiation and maturation of osteoblasts are necessary for bone regeneration, and they play an important role in implant osseointegration. Six different osteogenic genes were studied. Of them, three were related to extracellular matrix synthesis (early expression genes) and the other three were related to extracellular matrix mineralization (late expression genes). However, these two categories are not strictly determined, because the expression of osteogenic genes is a dynamic process influenced by several factors. COL1, ALPL and IBSP genes are considered early markers, although their expression can be moderate or high during all differentiation processes, whereas BGLAP, SPARC, and SSP1 are considered late markers [55]. Cells grown on $\mathrm{ZnO}$ nanosheets presented similar or higher levels of all genes analyzed (except for IBSP at 14 days) compared with cells grown on pristine alloy. In addition, cells grown on $\mathrm{ZnO}$ nanosheets presented similar or higher levels of the genes analyzed compared with cells grown on the $\mathrm{ZnO}$ thin film, except for COL1 and IBSP on day 14 and SPARC on day 21. Overall, these results suggest that $\mathrm{ZnO}$ nanosheets enhance the expression of some osteoblast differentiation markers, mainly early expression genes. As previously discussed, the increase in differentiation could be due to the local electric field generated by $2 \mathrm{D}$ nanostructured $\mathrm{ZnO}$ nanosheets. Although there are several studies describing osteoblast gene expression under electrical stimulation $[47,56]$, there is not a consensus of how gene expression is modulated under electrical stimulation. This is due, in part, to the variability in the parameters used in each study (i.e., voltage, time under electrical stimuli, cell line, etc.), which hampers comparisons between studies. In addition, in the present work, it was not feasible to measure the voltage or times that cells had been stimulated, because this depends on the cell movements. However, the generation of a local electric field due to cell movement, without the need of external stimulation, is an important point for bone tissue regeneration. 


\section{Conclusions}

In summary, we can conclude that the hybrid material made of a metallic TiZrPdSiNb alloy and covered with hydrothermally grown $\mathrm{ZnO}$ nanosheets is not cytotoxic. Additionally, the material does not induce an inflammatory response (i.e., cytokine release is null or very low for TNF- $\alpha$, IL-6 or IL-1 $\beta$ ) after $24 \mathrm{~h}$ in culture and, more importantly, it improves the proliferation of Saos- 2 cells by a factor of 1.5 after seven days in culture. Finally, it enhances the expression of some early differentiation expression genes without the need of any electrical or chemical external stimuli. In particular, the levels of the studied genes up to 21 days are similar or higher for cells grown on $\mathrm{ZnO}$ nanosheets as compared to the uncoated alloy (except for IBSP on day 14) and ZnO thin film (except for COL1 and IBSP on day 14 and SPARC on day 21). The generally higher levels detected for the $\mathrm{ZnO}$ nanosheets are due to a self-stimulation mechanism which is triggered by the motion of cells and the concomitant strains generated with the $\mathrm{ZnO}$ nanosheets. As a result, local electric fields which boost cell proliferation and differentiation built up due to piezoelectricity. These beneficial effects were not observed when a flat $\mathrm{ZnO}$ thin film was deposited on the alloy surface by sputtering because of the full mechanical clamping. The obtained results will certainly have an important impact on surface nanoengineering of smart bioimplants with enhanced performance.

Author Contributions: Conceptualization, E.P., E.I., J.S., G.M. and C.N.; Data curation, O.C. and J.F.; Formal analysis, O.C., J.F., E.P. and A.B.; Funding acquisition, E.P., J.S., G.M. and C.N.; Investigation, E.P. and J.E.; Methodology, J.F., A.B., J.E., G.M. and C.N.; Software, O.C.; Supervision, C.N.; Validation, E.I.; Writing-Original draft preparation, O.C., E.P. and C.N.; Writing—Review and editing, E.P., E.I., J.E., J.S., G.M. and C.N. All authors have read and agreed to the published version of the manuscript.

Funding: This work has been partially supported by the 2017-SGR-292, 2017-SGR-503 and 2017-SGR1420 projects from the Generalitat de Catalunya, and the MAT2017-86357-C3-1-R (co-financed by the Fondo Europeo de Desarrollo Regional, FEDER), MAT2017-86357-C3-3-R and EUR2020-112082 projects from the Spanish Ministerio de Economía y Competitividad (MINECO), and La Caixa Foundation under the Junior Leader Retaining program (LCF/BQ/PR19/11700010).

Institutional Review Board Statement: Not applicable.

Informed Consent Statement: Not applicable.

Data Availability Statement: The data presented in this study are available on request from the corresponding author. The data are not publicly available due to their use in further studies.

Acknowledgments: The authors would like to thank the staff at the Servei de Microscòpia de la Universitat Autònoma de Barcelona and the IMB-CNM (CSIC) cleanroom.

Conflicts of Interest: The authors declare no conflict of interest.

\section{References}

1. Alvarez, K.; Nakajima, H. Metallic Scaffolds for Bone Regeneration. Materials 2009, 2, 790-832. [CrossRef]

2. Parai, R.; Bandyopadhyay-Ghosh, S. Engineered bio-nanocomposite magnesium scaffold for bone tissue regeneration. J. Mech. Behav. Biomed. Mater. 2019, 96, 45-52. [CrossRef]

3. Kumar, S.; Nehra, M.; Kedia, D.; Dilbaghi, N.; Tankeshwar, K.; Kim, K.-H. Nanotechnology-based biomaterials for orthopaedic applications: Recent advances and future prospects. Mater. Sci. Eng. C 2020, 106, 110154. [CrossRef]

4. Hynowska, A.; Blanquer, A.; Pellicer, E.; Fornell, J.; Suriñach, S.; Baro, M.D.; Gebert, A.; Calin, M.; Eckert, J.; Nogues, C.; et al. Nanostructured Ti-Zr-Pd-Si-(Nb) bulk metallic composites: Novel biocompatible materials with superior mechanical strength and elastic recovery. J. Biomed. Mater. Res. Part B Appl. Biomater. 2014, 103, 1569-1579. [CrossRef] [PubMed]

5. Hynowska, A.; Pellicer, E.; Fornell, J.; González, S.; Van Steenberge, N.; Suriñach, S.; Gebert, A.; Calin, M.; Eckert, J.; Baró, M.D.; et al. Nanostructured $\beta$-phase Ti-31.0Fe-9.0Sn and sub- $\mu \mathrm{m}$ structured Ti-39.3Nb-13.3Zr-10.7Ta alloys for biomedical applications: Microstructure benefits on the mechanical and corrosion performances. Mater. Sci. Eng. C 2012, 32, 2418-2425. [CrossRef]

6. Ghosh, S.; Dasharath, S.M.; Mula, S. Simulation Kinetics of Austenitic Phase Transformation in Ti+Nb Stabilized IF and Microalloyed Steels. J. Mater. Eng. Perform. 2018, 27, 2595-2608. [CrossRef]

7. Niinomi, M. Mechanical properties of biomedical titanium alloys. Mater. Sci. Eng. A 1998, 243, 231-236. [CrossRef] 
8. Kumar, A.; Nune, K.C.; Misra, R. Understanding the response of pulsed electric field on osteoblast functions in three-dimensional mesh structures. J. Biomater. Appl. 2016, 31, 594-605. [CrossRef] [PubMed]

9. Kamachimudali, U.; Sridhar, T.M.; Raj, B. Corrosion of bio implants. Sadhana 2003, 28, 601-637. [CrossRef]

10. Karimi, S. Corrosion Behavior of Metallic Bio-Implan Alloys. Ph.D. Thesis, University of British Columbia, Vancouver, BC, Canada, 2014.

11. Hanada, S.; Matsumoto, H.; Watanabe, S. Mechanical compatibility of titanium implants in hard tissues. Int. Congr. Ser. 2005, 1284, 239-247. [CrossRef]

12. Wang, Q.Q.; Li, W.; Yang, B.C. Regulation on the biocompatibility of bioactive titanium metals by type I collagen. J. Biomed. Mater. Res. Part A 2011, 99, 125-134. [CrossRef]

13. Zhang, L.; Chen, L. A Review on Biomedical Titanium Alloys: Recent Progress and Prospect. Adv. Eng. Mater. 2019, 21, 1801215. [CrossRef]

14. Li, Y.; Yang, C.; Zhao, H.; Qu, S.; Li, X.; Li, Y. New Developments of Ti-Based Alloys for Biomedical Applications. Materials 2014, 7, 1709-1800. [CrossRef]

15. Bauer, S.; Schmuki, P.; Von Der Mark, K.; Park, J. Engineering biocompatible implant surfaces. Part I: Materials and surfaces. Prog. Mater. Sci. 2013, 58, 261-326. [CrossRef]

16. Batebi, K.; Khazaei, B.A.; Afshar, A. Characterization of sol-gel derived silver/fluor-hydroxyapatite composite coatings on titanium substrate. Surf. Coat. Technol. 2018, 352, 522-528. [CrossRef]

17. Vahabzadeh, S.; Roy, M.; Bandyopadhyay, A.; Bose, S. Phase stability and biological property evaluation of plasma sprayed hydroxyapatite coatings for orthopedic and dental applications. Acta Biomater. 2015, 17, 47-55. [CrossRef]

18. Yang, Y.-C.; Chang, E. Measurements of residual stresses in plasma-sprayed hydroxyapatite coatings on titanium alloy. Surf. Coatings Technol. 2005, 190, 122-131. [CrossRef]

19. Ao, H.; Xie, Y.; Tan, H.; Wu, X.; Liu, G.; Qin, A.; Zheng, X.; Tang, T. Improved hMSC functions on titanium coatings by type I collagen immobilization. J. Biomed. Mater. Res. Part A 2013, 102, 204-214. [CrossRef]

20. Müller, R.; Abke, J.; Schnell, E.; Scharnweber, D.; Kujat, R.; Englert, C.; Taheri, D.; Nerlich, M.; Angele, P. Influence of surface pretreatment of titanium- and cobalt-based biomaterials on covalent immobilization of fibrillar collagen. Biomaterials 2006, 27, 4059-4068. [CrossRef] [PubMed]

21. Morra, M.; Cassinelli, C.; Cascardo, G.; Bollati, D.; Baena, R.R.Y. Gene expression of markers of osteogenic differentiation of human mesenchymal cells on collagen I-modified microrough titanium surfaces. J. Biomed. Mater. Res. Part A 2010, 96, 449-455. [CrossRef]

22. Becker, J.; Lu, L.; Runge, M.B.; Zeng, H.; Yaszemski, M.J.; Dadsetan, M. Nanocomposite bone scaffolds based on biodegradable polymers and hydroxyapatite. J. Biomed. Mater. Res. Part A 2015, 103, 2549-2557. [CrossRef] [PubMed]

23. Hardy, J.G.; Geissler, S.A.; Aguilar, D.; Villancio-Wolter, M.K.; Mouser, D.J.; Sukhavasi, R.C.; Cornelison, R.C.; Tien, L.W.; Preda, R.C.; Hayden, R.S.; et al. Instructive Conductive 3D Silk Foam-Based Bone Tissue Scaffolds Enable Electrical Stimulation of Stem Cells for Enhanced Osteogenic Differentiation. Macromol. Biosci. 2015, 15, 1490-1496. [CrossRef]

24. George, P.M.; Bliss, T.M.; Hua, T.; Lee, A.; Oh, B.; Levinson, A.; Mehta, S.; Sun, G.; Steinberg, G.K. Electrical preconditioning of stem cells with a conductive polymer scaffold enhances stroke recovery. Biomaterials 2017, 142, 31-40. [CrossRef] [PubMed]

25. Mata, D.; Oliveira, F.J.; Neto, M.A.; Belmonte, M.; Bastos, A.C.; Lopes, M.A.; Gomes, P.S.; Fernandes, M.H.; Silva, R.F. Smart electroconductive bioactive ceramics to promote in situ electrostimulation of bone. J. Mater. Chem. B 2015, 3, 1831-1845. [CrossRef]

26. Narkevica, I.; Stipniece, L.; Jakobsons, E.; Cakstina, I.; Ozolins, J. Electrically active and 3D porous TiO 2-x ceramic scaffolds for bone tissue regeneration. J. Eur. Ceram. Soc. 2017, 37, 833-840. [CrossRef]

27. Choi, M.; Murillo, G.; Hwang, S.; Kim, J.W.; Jung, J.H.; Chen, C.-Y.; Lee, M. Mechanical and electrical characterization of PVDF-ZnO hybrid structure for application to nanogenerator. Nano Energy 2017, 33, 462-468. [CrossRef]

28. Dagdeviren, C.; Li, Z.; Wang, Z.L. Energy Harvesting from the Animal/Human Body for Self-Powered Electronics. Annu. Rev. Biomed. Eng. 2017, 19, 85-108. [CrossRef]

29. Murillo, G.; Leon-Salguero, E.; Martínez-Alanis, P.R.; Esteve, J.; Alvarado-Rivera, J.; Güell, F. Role of aluminum and HMTA in the hydrothermal synthesis of two-dimensional n-doped ZnO nanosheets. Nano Energy 2019, 60, 817-826. [CrossRef]

30. Marino, A.; Genchi, G.G.; Mattoli, V.; Ciofani, G. Piezoelectric nanotransducers: The future of neural stimulation. Nano Today 2017, 14, 9-12. [CrossRef]

31. Marino, A.; Arai, S.; Hou, Y.; Sinibaldi, E.; Pellegrino, M.; Chang, Y.-T.; Mazzolai, B.; Mattoli, V.; Suzuki, M.; Ciofani, G. Piezoelectric Nanoparticle-Assisted Wireless Neuronal Stimulation. ACS Nano 2015, 9, 7678-7689. [CrossRef] [PubMed]

32. Hoop, M.; Chen, X.-Z.; Ferrari, A.; Mushtaq, F.; Ghazaryan, G.; Tervoort, T.; Poulikakos, D.; Nelson, B.; Pané, S. Ultrasoundmediated piezoelectric differentiation of neuron-like PC12 cells on PVDF membranes. Sci. Rep. 2017, 7, 4028. [CrossRef]

33. Rajabi, A.H.; Jaffe, M.; Arinzeh, T.L. Piezoelectric materials for tissue regeneration: A review. Acta Biomater. 2015, $24,12-23$. [CrossRef]

34. Ciofani, G.; Danti, S.; D’Alessandro, D.; Ricotti, L.; Moscato, S.; Bertoni, G.; Falqui, A.; Berrettini, S.; Petrini, M.; Mattoli, V.; et al. Enhancement of Neurite Outgrowth in Neuronal-Like Cells following Boron Nitride Nanotube-Mediated Stimulation. ACS Nano 2010, 4, 6267-6277. [CrossRef] [PubMed]

35. Ciofani, G.; Genchi, G.G.; Mattoli, V. ZnO nanowire arrays as substrates for cell proliferation and differentiation. Mater. Sci. Eng. C 2012, 32, 341-347. [CrossRef] 
36. Kitsara, M.; Blanquer, A.; Murillo, G.; Humblot, V.; De Bragança Vieira, S.; Nogués, C.; Ibáñez, E.; Esteve, J.; Barrios, L. Permanently hydrophilic, piezoelectric PVDF nanofibrous scaffolds promoting unaided electromechanical stimulation on osteoblasts. Nanoscale 2019, 11, 8906-8917. [CrossRef]

37. Ribeiro, S.; Puckert, C.; Ribeiro, C.; Gomes, A.C.; Higgins, M.J.; Lanceros-Méndez, S. Surface Charge-Mediated Cell-Surface Interaction on Piezoelectric Materials. ACS Appl. Mater. Interfaces 2019, 12, 191-199. [CrossRef]

38. Lozano, H.; Catalán, G.; Esteve, J.; Domingo, N.; Murillo, G. Non-linear nanoscale piezoresponse of single ZnO nanowires affected by piezotronic effect. Nanotechnology 2021, 32, 025202. [CrossRef] [PubMed]

39. Reddy, K.M.; Feris, K.; Bell, J.; Wingett, D.G.; Hanley, C.; Punnoose, A. Selective toxicity of zinc oxide nanoparticles to prokaryotic and eukaryotic systems. Appl. Phys. Lett. 2007, 90, 213902. [CrossRef]

40. Padmavathy, N.; Vijayaraghavan, R. Enhanced bioactivity of ZnO nanoparticles-An antimicrobial study. Sci. Technol. Adv. Mater. 2008, 9, 035004. [CrossRef] [PubMed]

41. Murillo, G.; Blanquer, A.; Vargas-Estevez, C.; Barrios, L.; Ibáñez, E.; Nogués, C.; Esteve, J. Electromechanical Nanogenerator-Cell Interaction Modulates Cell Activity. Adv. Mater. 2017, 29, 1605048. [CrossRef]

42. Murillo, G.; Lozano, H.; Cases-Utrera, J.; Lee, M.; Esteve, J. Improving Morphological Quality and Uniformity of Hydrothermally Grown ZnO Nanowires by Surface Activation of Catalyst Layer. Nanoscale Res. Lett. 2017, 12, 51. [CrossRef]

43. Murillo, G.; Rodríguez-Ruiz, I.; Esteve, J. Selective Area Growth of High-Quality ZnO Nanosheets Assisted by Patternable AlN Seed Layer for Wafer-Level Integration. Cryst. Growth Des. 2016, 16, 5059-5066. [CrossRef]

44. Saldaña, L.; Bensiamar, F.; Boré, A.; Vilaboa, N. In search of representative models of human bone-forming cells for cytocompatibility studies. Acta Biomater. 2011, 7, 4210-4221. [CrossRef] [PubMed]

45. Blanquer, A.; Musilkova, J.; Barrios, L.; Ibáñez, E.; Vandrovcova, M.; Pellicer, E.; Sort, J.; Bacakova, L.; Nogués, C. Cytocompatibility assessment of Ti-Zr-Pd-Si-(Nb) alloys with low Young's modulus, increased hardness, and enhanced osteoblast differentiation for biomedical applications. J. Biomed. Mater. Res. Part B Appl. Biomater. 2017, 106, 834-842. [CrossRef]

46. Khatib, L.; Golan, D.E.; Cho, M. Physiologic electrical stimulation provokes intracellular calcium increase mediated by phospholipase C activation in human osteoblasts. FASEB J. 2004, 18, 1903-1905. [CrossRef]

47. Meng, S.; Zhang, Z.; Rouabhia, M. Accelerated osteoblast mineralization on a conductive substrate by multiple electrical stimulation. J. Bone Miner. Metab. 2011, 29, 535-544. [CrossRef]

48. Lee, J.; Kang, B.; Hicks, B.; Chancellor, T.F., Jr.; Chu, B.H.; Wang, H.-T.; Keselowsky, B.G.; Ren, F.; Lele, T.P. The control of cell adhesion and viability by zinc oxide nanorods. Biomaterials 2008, 29, 3743-3749. [CrossRef] [PubMed]

49. Park, J.K.; Kim, Y.-J.; Yeom, J.; Jeon, J.H.; Yi, G.-C.; Je, J.H.; Hahn, S.K. The Topographic Effect of Zinc Oxide Nanoflowers on Osteoblast Growth and Osseointegration. Adv. Mater. 2010, 22, 4857-4861. [CrossRef] [PubMed]

50. Wang, W.; Khoon, C. Titanium Alloys in Orthopaedics. In Titanium Alloys Advances in Properties Control; Sieniawski, J., Ziaja, W., Eds.; IntechOpen: London, UK, 2013. [CrossRef]

51. Tang, L.; Eaton, J.W. Inflammatory Responses to Biomaterials. Am. J. Clin. Pathol. 1995, 103, 466-471. [CrossRef]

52. De Peppo, G.M.; Agheli, H.; Karlsson, C.; Ekstrom, K.; Brisby, H.; Lenneras, M.; Gustafsson, S.; Sjövall, P.; Johansson, A.; Olsson, E.; et al. Osteogenic response of human mesenchymal stem cells to well-defined nanoscale topography in vitro. Int. J. Nanomed. 2014, 9, 2499-2515. [CrossRef]

53. Olivares-Navarrete, R.; Hyzy, S.L.; Berg, M.E.; Schneider, J.M.; Hotchkiss, K.; Schwartz, Z.; Boyan, B.D. Osteoblast Lineage Cells Can Discriminate Microscale Topographic Features on Titanium-Aluminum-Vanadium Surfaces. Ann. Biomed. Eng. 2014, 42, 2551-2561. [CrossRef] [PubMed]

54. Özkucur, N.; Monsees, T.K.; Perike, S.; Do, H.Q.; Funk, R.H.W. Local Calcium Elevation and Cell Elongation Initiate Guided Motility in Electrically Stimulated Osteoblast-Like Cells. PLoS ONE 2009, 4, e6131. [CrossRef] [PubMed]

55. Przekora, A. The summary of the most important cell-biomaterial interactions that need to be considered during in vitro biocompatibility testing of bone scaffolds for tissue engineering applications. Mater. Sci. Eng. C 2019, 97, 1036-1051. [CrossRef] [PubMed]

56. Griffin, M.; Sebastian, A.; Colthurst, J.; Bayat, A. Enhancement of Differentiation and Mineralisation of Osteoblast-like Cells by Degenerate Electrical Waveform in an In Vitro Electrical Stimulation Model Compared to Capacitive Coupling. PLoS ONE 2013, 8, e72978. [CrossRef] 